\title{
ヒト血管内皮細胞における細胞傷害性試験およびウサギ血管刺激性試験 によるニカルジピン塩酸塩誘発血管障害の危険因子の解析
}

\author{
越智幹記 ${ }^{* 1}$ ，掛樋善明 ${ }^{2}$, 田中祥之 ${ }^{1}$, 豊田 弘 $^{1}$, 石原正一郎 ${ }^{2}$ \\ 沢井製薬株式会社生物研究部 ${ }^{1}$, 埼玉医科大学国際医療セン夕ー脳神経外科 脳血管内治療科 ${ }^{2}$

\section{Characterization of Risk Factor of Nicardipine hydrochloride-induced Venous Study in Rabbit Ear Vein} \\ Irritation with Cytotoxicity Test on Human Vascular Endothelial Cells and Irritability
}

\author{
Masanori Ochi ${ }^{1}$ Yoshiaki Kakehi', Yoshiyuki Tanaka ${ }^{1}$, Hiromu Toyoda ${ }^{1}$ and Shoichiro Ishihara ${ }^{2}$ \\ Biological Research Department, Sawai Pharmaceutical Co, Ltd ${ }^{1}$, \\ Department of Endovascular Neurosurgery, International Medical Center, Saitama Medical University ${ }^{2}$ \\ $\left[\begin{array}{l}\text { Received February 17, } 2015 \\ \text { Accepted September 29, } 2015\end{array}\right]$
}

Nicardipine hydrochloride injection is widely used for emergency treatment of abnormally high blood pressure. However, nicardipine hydrochloride injection often causes severe peripheral vascular injury. The goal of this study was to reduce vascular injury by nicardipine hydrochloride injection. Here, we investigated the characteristics of nicardipine hydrochloride-induced vascular injury with human dermal microvascular endothelial cells (HMVECs) in an irritability study in the rabbit ear vein. Nicardipine hydrochloride decreased cell viability and increased percentage of dead cells in a dose-dependent manner. The results from the irritability study in the rabbit ear vein suggest that the administration rate and drug concentration were related to venous and perivascular tissue injury. Thus, administration rate, drug concentration, and blood flow rate at the injection site were important factors for the reduction of nicardipine hydrochloride-induced venous irritation.

Key words — nicardipine hydrochloride, cytotoxicity, vascular injury, endothelial cells, irritability study

\section{緒 言}

ニカルジピン塩酸塩注射液は手術時の異常高血 圧の救急処置, 高血圧性緊急症, 急性心不全に適 応を持ち, 速やかな薬効と少ない副作用のため有 用性が高く，経口投与が難しい患者や緊急の高血 圧の治療に広く臨床使用されている。しかしなが ら, 治療継続の妨げとなる副作用の 1 つとして静 脈内投与後の血管障害が報告されており，発症頻 度は約 34～39\% と報告されている. ${ }^{1,2)}$ 埼玉医科大 学国際医療センターでも, 脳出血, クモ膜下出血, 脳動脈瘤の患者などにニカルジピン塩酸塩注射液 を使用しているが，末梢静脈から投与した場合に は静脈炎を発現することがある。 ニカルジピン塩
酸塩注射液による静脈炎および血管周囲組織の障 害は, 疼痛, 紅斑 / 浮腫, 熱感などの症状を呈し, 患者の quality of life は著しく低下する。 また，薬 剂投与の中断を余儀なくされ, 静脈炎の治療も行 う必要があるため医療従事者の負担も増加する。 そのため, ニカルジピン塩酸塩注射液による静脈 炎の要因をさらに解明し, 発現頻度を減らすこと は極めて重要な課題である.

静脈炎の主な要因として $\mathrm{pH}$, 滴定酸度, 浸透 圧が報告されている. ${ }^{3)}$ 成重らの報告ではニカルジ ピン塩酸塩注射液の投与時間と投与速度が静脈炎 の発症頻度に影響するという臨床的に非常に有用 な報告がなされているが, 投与時間が 24 時間を超 えた例すべてで血管障害が発症するとは限らず,

\footnotetext{
*T532-0003 大阪市淀川区宮原5-2-30
} 
投与速度が $45 \mathrm{~mL} / \mathrm{h}$ を超えた例でも血管障害が認 められていない患者も存在し, ${ }^{1}$ ニカルジピン塩酸 塩注射液の静脈内投与による血管障害の要因のさ らなる解明が期待されている。 そこで, 本研究で はニカルジピン塩酸塩注射液の静脈内投与による 血管障害発現の危険因子を明らかにすることを目 的とし，ヒト血管内皮細胞およびウサギの後耳介 静脈を用いた血管障害評価モデルにより薬物濃度 および暴露時間が血管内皮細胞傷害性に及ぼす影 響を検討し，in vivoで投与速度および投与濃度が 血管障害の発現に及ぼす影響について検討した。

\section{方 法}

\section{1. 試薬}

製剂および原薬としてニカルジピン塩酸塩注射 液「サワイ」およびニカルジピン塩酸塩（Lot A805579）を用いた。D-ソルビトール，ヨウ化プ ロピジウムおよび Calcein AM は和光純薬工業(株) (大阪)から購入した。その他の試薬は市販されて いる試薬を用いた。

\section{2. 細胞}

ヒト血管内皮細胞（成人由来正常ヒト皮虐微小 血管内皮細胞：HMVECs）はエーディア(株)(東 京)より購入し, 添付文書に従って培養した。細 胞の培地はブレットキット EGM-2MV（血管内皮 細胞用増殖培地）を用い, $\mathrm{CO}_{2}$ チャンバーの条件 は $37^{\circ} \mathrm{C} ， 5 \% \mathrm{CO}_{2}$ とした。細胞傷害性試験には 5 15 継代のものを用いた.

\section{Calcein AM を用いた細胞生存率の評価 (Calcein AM assay)}

HMVECs を 96 ウェルプレートの各ウェルに播 種後にコンフルエントになるまで前培養し，製剤 であるニカルジピン塩酸塩注射液および原薬（ニ カルジピン塩酸塩として 10～30 $\mu \mathrm{g} / \mathrm{mL} ）$ 並びに添 加物の D-ソルビトール $(1.5 \mathrm{mg} / \mathrm{mL})$ を血管内皮 細胞用増殖培地で目的濃度に調整し 24 時間暴露 した $(200 \mu \mathrm{L} / \mathrm{well})$. 24 時間暴露後に Calcein AM $10 \mu \mathrm{g} / \mathrm{mL}$ を $20 \mu \mathrm{L}$ 添加し, $37^{\circ} \mathrm{C}, 5 \% \mathrm{CO}_{2}$ 条件下 で 30 分インキュベーション後の蛍光強度をプレー
トリーダー (Infinite M1000, Tecan) により測定した. $\lambda_{\text {em }}$ および $\lambda_{\text {ex }}$ はそれぞれ $490 \mathrm{~nm}$ および $520 \mathrm{~nm}$ と した. Calcein AM はほとんど蛍光を示さない細胞 膜透過性の物質であるが, 生細胞内にあるエステ ラーゼによって細胞膜非透過の蛍光物質である Calcein に分解される. ${ }^{4)}$ そのため, 薬物暴露 24 時 間後における薬物暴露群と薬物非暴露群の蛍光強 度の比から細胞生存率を評価した。

\section{4. ヨウ化プロピジウム（PI）を用いた細胞膜} 傷害性の評価（PI uptake assay）

HMVECs を 96 ウェルプレートの各ウェルに播 種後にコンフルエントになるまで前培養し, 各ウェ ルにヨウ化プロピジウム（PI，終濃度 $20 \mu \mathrm{g} / \mathrm{mL}$ ） を添加し, ニカルジピン塩酸塩注射液（ニカルジ ピン塩酸塩として 10〜30 $\mu \mathrm{g} / \mathrm{mL}$ ) を添加後 0 お よび 24 時間の蛍光強度を測定した ${ }^{5)}$ 蛍光強度は プレートリーダーにより測定し， $\lambda_{\mathrm{em}}$ および $\lambda_{\mathrm{ex}}$ は それぞれ $540 \mathrm{~nm}$ および $615 \mathrm{~nm}$ とした。薬物非 暴露の細胞のウェルの蛍光強度を $100 \%$ とした時 の蛍光強度増加率から細胞生存率について評価を 行った。ニカルジピン塩酸塩注射液の希釈は培地 にて行い, PI uptake assay の結果の妥当性を評価 するため, 同時に Calcein AM assay を実施した.

\section{5. ライブセルイメージングによる経時的な死細 胞増加推移の測定}

HMVECs を 8-well チャンバー（松浪硝子(株), 大阪）に播種後にコンフルエントになるまで前培 養し, ニカルジピン塩酸塩として $30 \mu \mathrm{g} / \mathrm{mL}$ を HMVECs に暴露後の継時的な細胞形態変化を撮影 した，また，死細胞はPI $(1 \mu \mathrm{g} / \mathrm{mL})$ によって検 出し, PI 陽性の細胞を死細胞と判定した。蛍光顕 微鏡（BZ-9000，(株)キーエンス, 大阪）によって, 15 分間隔，20 倍の倍率で撮影を実施した。測定 中の細胞培養条件は $37^{\circ} \mathrm{C} ， 5 \% \mathrm{CO}_{2}$ とした。

\section{6. 動物}

生後 15 週齢の JW/CSK 雄ウサギを日本エスエ ルシー (株) (静岡)より購入し, 1 週間の予備飼育 を行った後に, 試験に供した. 動物は温度 $23 \pm$ $3^{\circ} \mathrm{C}$, 湿度 $50 \pm 10 \%$, 照明時間 8：00 20：00 
とした動物室内で飼育し, 自由飲水, 自由摂食と した。本研究は沢井製薬 (株) 倫理委員会の承認を 受けて行った（承認番号：24-11）。

\section{7. ウサギ後耳介静脈への投与および病理組織学 的観察}

ニカルジピン塩酸塩注射液の血管刺激性を検討 するために, ウサギの耳介静脈に点滴静注を実施 した。すなわち，ニカルジピン塩酸塩注射液およ び希釈液を 15 60 mL/h の投与速度で静脈内に投 与した。注射針はテルモ $25 \mathrm{G}$ の翼付を用いた。 ニ カルジピン塩酸塩注射液の希釈溶液は用時調製と し, 生理食塩液によって希釈した。 また, 対象群 （Control）には生理食塩液を投与した。単回投与 48 時間後における病理組織観察のため, 投与 48 時間後に動物を二酸化炭素により安楽死させ, 耳 介を摘出後，10\%中性緩衝ホルマリン液にて固定 した，病理組織学的観察のために，針先から心臓 側に 5 10 mm の位置で薄切切片を作成し, HE （hematoxylin eosin）染色後に倍率 20 および 40 倍 で光学顕微鏡観察を実施した，注射剤の血管刺激 性の有無を判定する評価方法として，血管の変化 （血管拡張，血管壁の変性，内皮細胞の変化，血栓 形成), 血管周囲組織の変化（出血，細胞浸潤，変 性, 線維化, 浮腫, フィブリン析出）が広く利用さ れている. ${ }^{677}$ 我々は上記の指標のなかで客観的に評 価可能で間隔尺度である血管の拡張および血管周 囲組織の浮腫について統計学的な比較を実施した。

\section{8. 統計解析}

多重比較検定は等分散性の検定の後に Williams' test または Shirley-Williams' test を実施した。P值 が 0.05 より小さい時に統計学的に有意な差があ るとした。データは EXSUS（Version 8.1; CAC EXICARE, Tokyo, NC）および SAS（Ver 9.4, SAS Institute Inc, Cary, NC）によって解析した.

\section{結果および考察}

\section{1. 原薬および添加物が HMVECs の細胞生存 率に及ぼす影響}

ニカルジピン塩酸塩注射液中のいずれの成分が
細胞傷害の原因となっているかを検討するため, 原薬, 添加物である D-ソルビトールおよび製剤 であるニカルジピン塩酸塩注射液のそれぞれが細 胞生存率に及ぼす影響を Calcein AM assay によっ て評価した（図1)。製椷（ニカルジピン塩酸塩 注射液）と原薬（ニカルジピン塩酸塩）の 24 時 間暴露によって濃度依存的に細胞生存率は減少 し, 細胞生存率低下の濃度依存的なプロファイル はほほ一致した。一方，D-ソルビトールは $30 \mu \mathrm{g} /$ $\mathrm{mL}$ のニカルジピン塩酸塩注射液を暴露した時に 含まれる濃度の $1.5 \mathrm{mg} / \mathrm{mL}$ を暴露しても有意な細 胞生存率の減少は認められなかったため（data not shown), ニカルジピン塩酸塩注射液による血 管障害の主因は添加物ではなく, 主成分のニカル ジピン塩酸塩だと考えられた。

\section{2. ニカルジピン塩酸塩注射液を暴露後の死亡細 胞増加の経時的推移}

ニカルジピン塩酸塩注射液による細胞膜傷害性 試験の結果を図 2 に示す。ニカルジピン塩酸塩と して $30 \mu \mathrm{g} / \mathrm{mL}$ の濃度のニカルジピン塩酸塩注射 液を暴露して 30 分以内に細胞内に小胞が増加し, 暴露後 6〜9 時間にかけてヨウ化プロピジウムの 蛍光強度が増加した. ヨウ化プロピジウムは細胞 膜非透過型の DNA 染色試薬であり DNA との結 合により蛍光強度が増加するため, ${ }^{8)}$ ニカルジピ ン塩酸塩注射液を添加後 6〜9 時間にかけて細胞

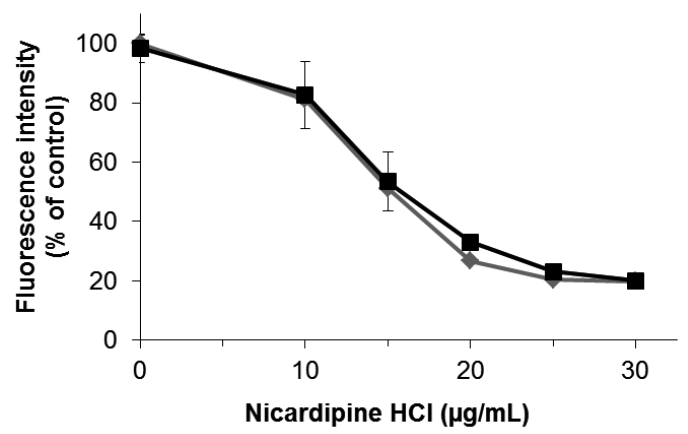

図1原薬および製剤の濃度依存的な細胞生存率の 低下，ニカルジピン塩酸塩として 10, 12.5, 15, 17.5, 20, 22.5, 25, $30 \mu \mathrm{g} / \mathrm{mL}$ を血管内皮細胞に暴 露 24 時間後に Calcein AM assay により細胞生 存率を評価

原薬, \製剂. ニカルジピン塩酸塩注射液, 平均 \pm 標準偏差 $(\mathrm{n}=3)$, duplicate. 
膜が傷害されたと考えられた．薬物暴露から細胞 傷害までタイムラグがあるという本結果は，投与 から 14 時間以後に血管障害が発現しやすいとい
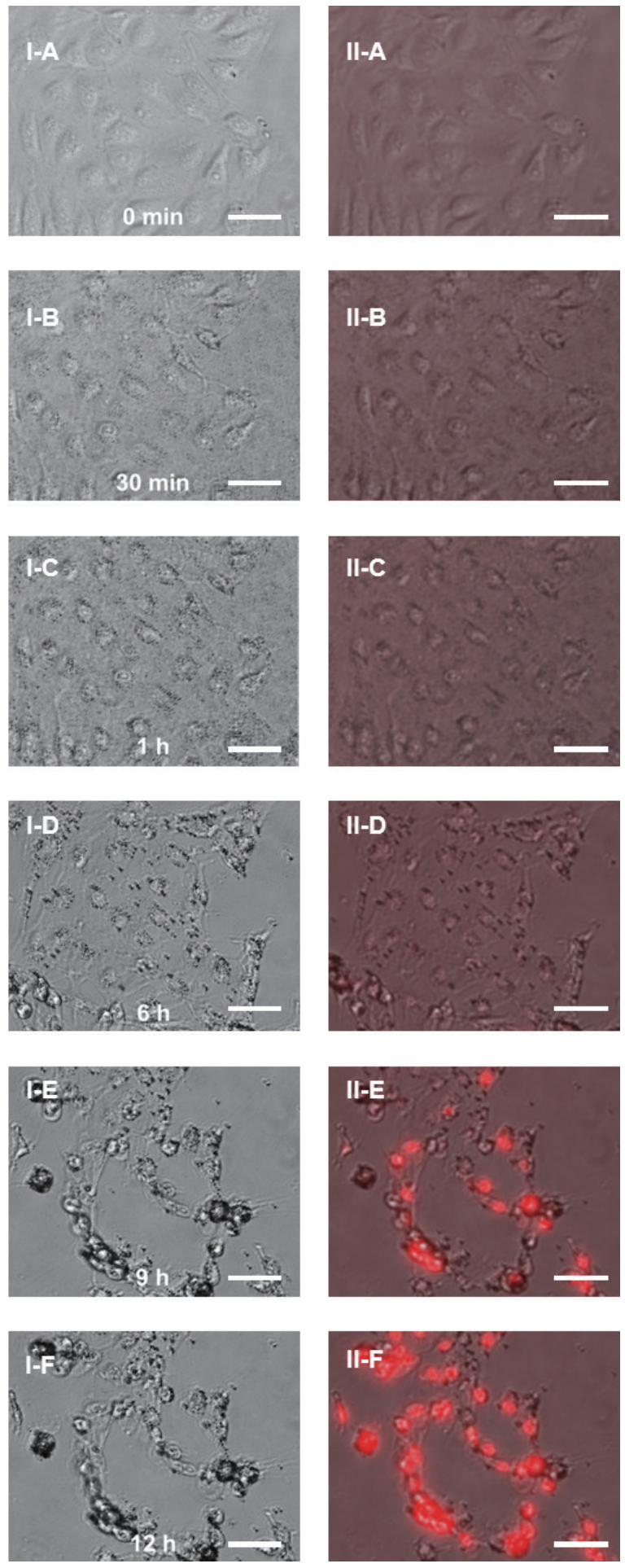

図 2 ニカルジピン塩酸塩注射液 (ニカルジピン塩 酸塩として $30 \mu \mathrm{g} / \mathrm{mL}$ ）を暴露後の経時的な細 胞形態変化

I : 位相差顕微鏡観察画像, II : 位相差顕微鏡観察画像とヨウ化 プロピジウム染色画像の重ね合わせ。 ニカルジピン塩酸塩注射 液を暴露直後 $(\mathrm{A}), 0.5(\mathrm{~B}), 1(\mathrm{C}) ， 6(\mathrm{D}), 9(\mathrm{E}), 12(\mathrm{~F})$ 時間 後に撮影した画像. $\mathrm{Bar}=50 \mu \mathrm{m}$.
う臨床報告と一致した. ${ }^{2)}$ 従って, 血管内皮細胞 の細胞膜が傷害される 9 時間以後に投与部位に注 意することが必要であり，特に投与後 12〜24 時 間にかけての投与部位のモニタリングがニカルジ ピン塩酸塩注射液による血管障害の早期発見に有 用であると考えられる.

\section{3. ニカルジピン塩酸塩注射液による細胞傷害性 の濃度依存性}

ニカルジピン塩酸塩注射液が細胞傷害性を示す 濃度の閥值を細胞傷害性および細胞生存率の低下 により評価した結果, ニカルジピン塩酸塩として 15 $\mu \mathrm{g} / \mathrm{mL}$ 以上の濃度ではヨウ化プロピジウムの蛍光強 度の増加と Calcein AM の蛍光強度の低下が認めら れ, 死亡細胞の増加と細胞生存率の低下が認めら れた（図 3)。一方，二カルジピン塩酸塩として 12.5 $\mu \mathrm{g} / \mathrm{mL}$ 以下の濃度ではわずかに細胞生存率が低下 したものの細胞膜傷害は認められず, Calcein AM assay と PI uptake assay の濃度依存性は一致した。

\section{4. ウサギ耳介静脈にニカルジピン塩酸塩注射液 を投与時の血管および血管周囲組織の形態変 化および投与濃度, 投与速度, 血流制限が組 織傷害性に与える影響}

生理食塩液抒よびニカルジピン塩酸塩注射液 ( $1 \mathrm{mg} / \mathrm{mL}, 3 \mathrm{~mL}$ ) $60 \mathrm{~mL} / \mathrm{hour}$ の投与速度で投

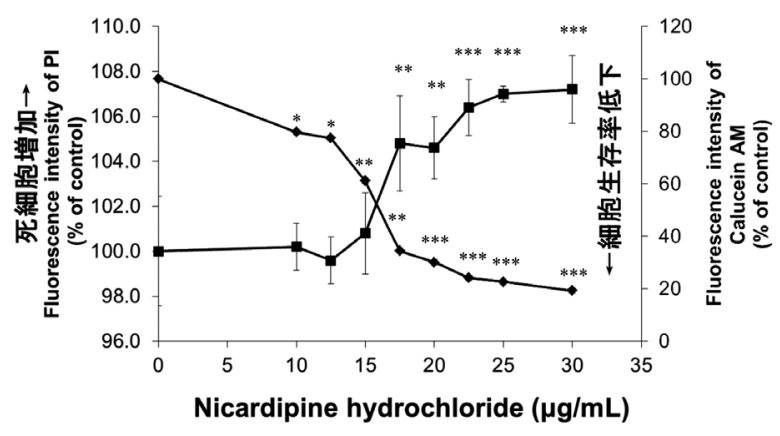

図 3 濃度依存的なニカルジピン塩酸塩注射液による 細胞生存率 /死細胞率の変化

HMVECs (human dermal microvascular endothelial cells) をニカ ルジピン塩酸塩注射液（ニカルジピン塩酸塩注射液として 10 〜30 $\mu \mathrm{g} / \mathrm{mL}$ ）に暴露後 24 時間における死細胞および細胞生存 率をそれぞれ PI uptake assay および Calcein AM assay により測 定. 平均 \pm 標準偏差 $(\mathrm{n}=3)$, duplicate. $* P<0.05, * * P<0.01$, $* * * P<0.001$ vs control. PI uptake, Williams' test; calcein AM assay, Shirley-Williams' test. 

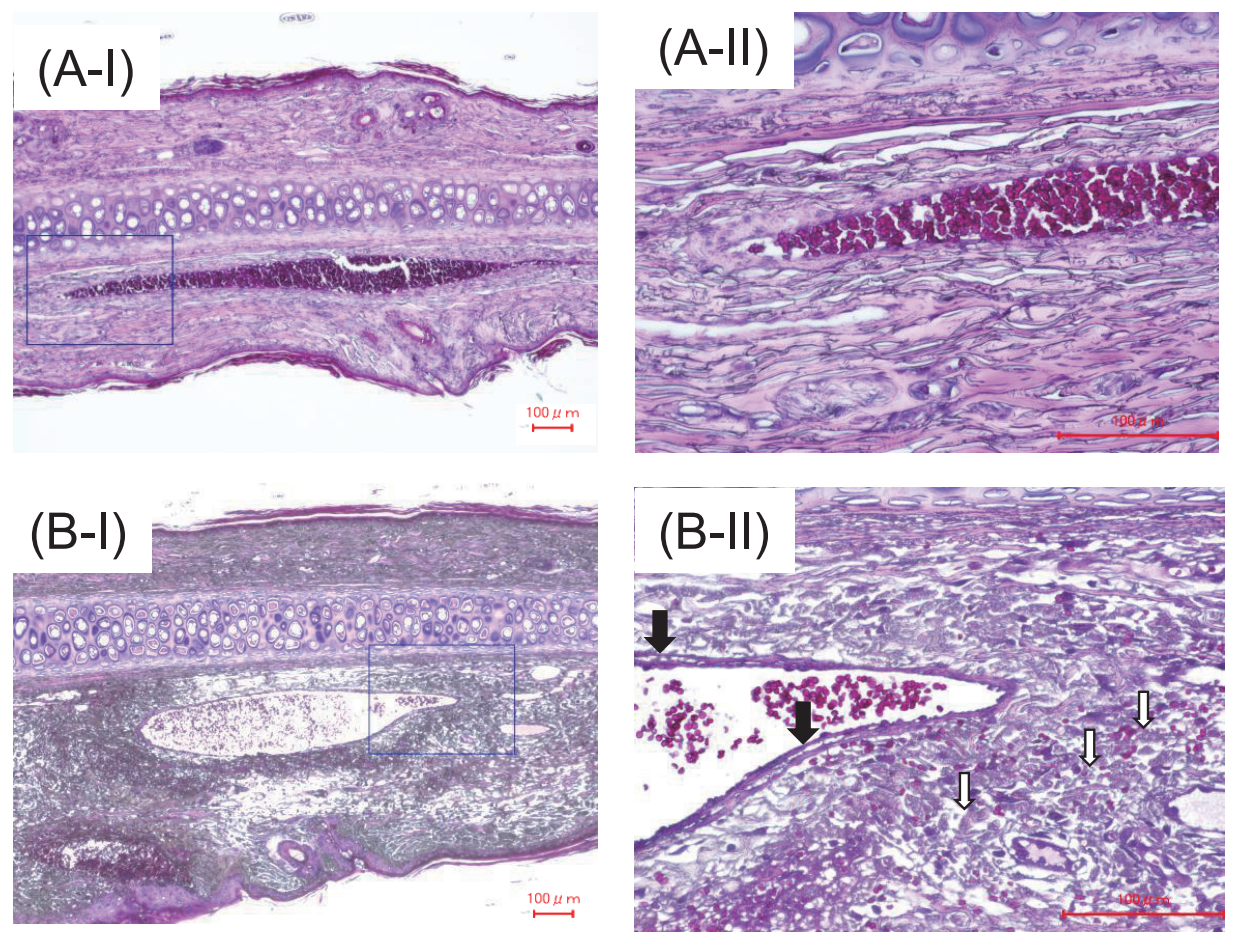

図 4 (A) 生理食塩液㧍よび（B）ニカルジピン塩酸塩注射液をウサギ後耳介静脈に投 与後 48 時間における投与部位の血管周囲組織の HE (hematoxylin eosin) 染色画像 白矢印：血管周囲組織の変性，黒矢印：血管内皮細胞の脱落㧍よび変性.

与し，投与 48 時間経過後のウサギ耳介血管およ び周囲組織切片を HE 染色した（図 4)。ニカル ジピン塩酸塩注射液を投与した血管では血管の拡 張，血管内皮細胞の脱落 (図中黒矢印)，血管周 囲組織の変性が認められた（図中白矢印）。一方， 生理食塩液を投与した部位には著変が認められな かった，血管障害性の評価指標として用いられて いる血管および組織の腫脹を用いて，薬物濃度お よび投与速度が血管障害に与える影響について検 討するために，ニカルジピン塩酸塩注射液を 60 $\mathrm{mL} /$ hour, $30 \mathrm{~mL} / \mathrm{hour}$, および $15 \mathrm{~mL} / \mathrm{hour}$ の投与速 度で投与した群の血管および組織の腫脹を比較し た結果，組織の腫脹は投与速度が遅い程有意に減 少した（表 1)。投与時の薬物濃度を一定として 投与速度を遅く，つまり血管内皮細胞への薬物暴 露時間を長くしても組織の腫脹が減少した理由と して，投与速度が遅い程流れてくる血液によって 希釈される割合が多くなることが考えられた。そ のため，血管障害を減らすためにはニカルジピン 塩酸塩注射液を太くて血流量の多い血管に投与す ることもリスク軽隇に有用であると考えられた。
表 1 投与速度が血管および組織の腫脹に及ぼす影響

\begin{tabular}{ccc}
\hline \hline 投与速度 & 血管の厚み $(\mu \mathrm{m})$ & 組織の厚み $(\mu \mathrm{m})$ \\
\hline $60 \mathrm{~mL} /$ hour & $171 \pm 115$ & $1053 \pm 201$ \\
$30 \mathrm{~mL} /$ hour & $50 \pm 42$ & $774 \pm 182^{*}$ \\
$15 \mathrm{~mL} /$ hour & $72 \pm 29$ & $807 \pm 77^{*}$ \\
\hline
\end{tabular}

$1 \mathrm{mg} / \mathrm{mL}$ のニカルジピン塩酸塩を含有するニカルジピン塩酸 塩注射液をウサギ後耳介静脈内に投与し, 投与 48 時間後にお ける血管および組織の厚みを測定した。平均 \pm 標準偏差 $(\mathrm{n}=$ $3-4), \quad * P<0.05$ vs $60 \mathrm{~mL} /$ hour (Williams 検定).

本結果は, 過去の臨床報告において, ニカルジピ ン塩酸塩注射液の投与速度に依存して, 血管障害 の発症頻度が増加するという報告と一致してお り, ${ }^{1}$ 投与速度はニカルジピン塩酸塩注射液によ る血管障害の要因となっていると考えられた。ニ カルジピン塩酸塩注射液の濃度を 3 倍, 5 倍希釈 して投与した結果, 組織の腫脤は濃度を低下させ ることで有意に減少した（表 2 )。さらに，二カ ルジピン塩酸塩注射液を使用する患者は麻痺に よって投与する腕の感覚がない場合があり, 無意 識に血管を圧迫して血流が減少する可能性が考え られたため, 血流の低下が血管障害に与える影響 
表 2 投与液の希釈倍率が血管および組織の腫脹に 及ぼす影響

\begin{tabular}{lcc}
\hline \hline $\begin{array}{c}\text { 希釈倍率 } \\
(\text { 濃度 }\end{array}$ & $\begin{array}{c}\text { 血管の厚み } \\
(\mu \mathrm{m})\end{array}$ & $\begin{array}{c}\text { 組織の厚み } \\
(\mu \mathrm{m})\end{array}$ \\
\hline 原液 $(1.0 \mathrm{mg} / \mathrm{mL})$ & $171 \pm 115$ & $1053 \pm 201$ \\
3 倍 $(0.33 \mathrm{mg} / \mathrm{mL})$ & $161 \pm 71$ & $697 \pm 39^{*}$ \\
5 倍 $(0.2 \mathrm{mg} / \mathrm{mL})$ & $43 \pm 34$ & $683 \pm 51^{*}$ \\
\hline
\end{tabular}

ニカルジピン塩酸塩注射液を $60 \mathrm{~mL} / \mathrm{hour}$ の投与速度でウサギ 後耳介静脈内に投与し，投与 48 時間後における血管および組 織の厚みを測定した。平均 \pm 標準偏差 $(\mathrm{n}=3-4), * P<0.05$ vs $1.0 \mathrm{mg} / \mathrm{mL}$ (Williams 検定).

表 3 血管圧迫が血管および組織の腫脹に及ぼす影響 血管圧迫の有無 血管の厚み $(\mu \mathrm{m})$ 組織の厚み $(\mu \mathrm{m})$

なし $50 \pm 42 \quad 774 \pm 182$

あり $125 \pm 50 \quad 900 \pm 183$

ニカルジピン塩酸塩注射液を $30 \mathrm{~mL} / \mathrm{hour}$ の投与速度でウサギ 後耳介静脈内に投与し, 投与 48 時間後における血管および組 織の厚みを測定した。投与部位より $20 \mathrm{~mm}$ 末梢側の血管をク リップでとめ，血流を制限して血管圧迫の影響を評価した。平 均 \pm 標準偏差 $(n=3-4)$.

について検討した（表 3)。クリップによる血管 の圧迫によって血流を低下させてニカルジピン塩 酸塩注射液を投与した結果，血管を圧迫していな い群と比較して血管を圧迫した群は血管および組 織の腫脹が増加したが有意な差は認められなかっ た（血管の厚み： $P=0.0626 ）$.

アメリカではニカルジピン塩酸塩注射液の Package insert (CARDENE IV- nicardipine hydrochloride injection, EKR Therapeutics, Inc, Bedminster, NJ, USA Revised:9/2010) の Warning and precautions $の$ 項目に「末梢血管刺激性のリスクを最小にするた めに，12 時間毎に投与部位を変更すること」と 記載されており, 定期的なカテーテル差し替えが 推奨されている。一方，本邦の添付文書では「本 凨を長時間投与し，注射部位に痛みや発赤などが みられた場合には，注入部位を変更すること」と 記載されており具体的な時間については記載され ていない，しかし，成重らの報告では 24 時間以 上のカテーテル挿入時間は血管障害のリスク因子 であることが報告されており， 定期的なカテー テル差し替えによって本邦でも血管障害の発現リ スクを低減できる可能性があると考えられる。

\section{5. 結論}

ニカルジピン塩酸塩注射液による血管障害は主 薬のニカルジピン塩酸塩の高濃度暴露による細胞 傷害が主な原因であると考えられ，ニカルジピン 塩酸塩注射液を投与する際は可能な限り希釈して ゆっくりと投与すること, 血流量の多い血管に投 与することが必要であると考えられた。

\section{利益相反}

開示すべき利益相反はない.

\section{引用文献}

1）成重友莉, 尾川理恵, 辰島瑶子, 福井史織, 江頭 伸昭, 光安正平, 坂井真樹, 桑城貴弘, 井無田 麻衣子, 大石了三, ICUに打けるニカルジピン注 射液による血管障害の危険因子の解析, 医療薬 学, 2012, 38, 541-546.

2) Wallin JD, Cook ME, Blanski L, Bienvenu GS, Clifton GG, Langford H, Turlapaty P, Laddu A, Intravenous nicardipine for the treatment of severe hypertension. Am J Med, 1988, 85, 331-338.

3) Stranz MP, Kastango ES, A review of $\mathrm{pH}$ and osmolarity, Int J Pharm Compd, 2002, 6, 216-220.

4) McGinnes K, Chapman G, Marks R, Penny R, A fluorescence NK assay using flow cytometry, J Immunol Methods, 1986, 86, 7-15.

5) Aki T, Egashira N, Hama M, Yamauchi $Y$, Yano T, Itoh Y, Oishi R, Characteristics of gabexate mesilateinduced cell injury in porcine aorta endothelial cells, J Pharmacol Sci, 2008, 106, 415-422.

6) Kuwahara $T$, Asanami $S$, Tamura $T$, Kaneda $S$, Effects of $\mathrm{pH}$ and osmolality on phlebitic potential of infusion solutions for peripheral parenteral nutrition, J Toxicol Sci, 1998, 23, 77-85.

7) Kawano S, Kondoh H, Ishikawa K, Koizumi S, Kadota T, Norimitsu T, Irritability study of paclitaxel in rabbit ear vein, J Toxicol Sci, 1994, 19 Supplement, 123-130.

8) Taylor IW, Milthorpe BK, An evaluation of DNA fluorochromes, staining techniques, and analysis for flow cytometry. I. Unperturbed cell populations, J Histochem Cytochem, 1980, 28, 1224-1232. 